\title{
Effects of Light Stimulation Age on Body Weight and Egg Production Traits of Broiler Pure-lines in the Laying Period
}

\author{
Musa Sarıca $^{1, a}$, Beyhan Yeter $^{2, b}$, Emrah Oğuzhan ${ }^{3, c}, K^{3}$ adir Erensoy ${ }^{1, d, *}$, \\ Sinan Çağlak ${ }^{3, \mathrm{e}}$, İsmail Özkan ${ }^{3, \mathrm{f}}$, Ramazan Yavuz $^{3, \mathrm{~g}}$ \\ ${ }^{1}$ Department of Animal Science, Agricultural Faculty, Ondokuz Mayls University, 55200 Samsun, Turkey, \\ ${ }^{2}$ Department of Animal Science Agricultural Faculty, Kahramanmaras Sütcü Imam University, 46100 Kahramanmaraş, Turkey, \\ ${ }^{3}$ Transitional Zone Agricultural Research Institute, Republic of Turkey Ministry of Agriculture and Forestry, 26200 Eskişehir, Turkey
} *Corresponding author

\section{A R T I C L E I N F O A B S T R A C T}

Research Article

In this study, the effects of light stimulation at normal (NLS: 154 days) and early (ELS: 140 days) age on some physiological and reproductive traits in dam and sire broiler pure-lines were carried out during the laying period. The study was conducted with A1, A2, A3, A4 dam lines and B1, B2 sire lines up to 43 weeks of age, whose breeding studies were carried out in Eskişehir Geçit Kuşağı

Received : 22/09/2020

Accepted : 25/11/2020 Agricultural Research Institute. Live weight and feed consumption were determined during the growing period. In the laying period, in addition to these, the first laying age, $50 \%$ yield age, egg yield, hatching egg yield and egg weight were determined. The data obtained were evaluated according to light stimulation age and pure-lines by two factor analysis of variance. NLS and ELS treatments did not significantly affect the body weights of the pure-lines at 20,24 and 43 weeks of

Keywords:

Broiler pure-lines age. However, differences were found significant in terms of body weight at 20, 24 and 43 weeks of age in pure-lines. Lines reached the first laying age at 172 days in NLS, and at 165 days of age in ELS. The $50 \%$ yield age was realized at $184 \mathrm{~d}$ and $176 \mathrm{~d}$ of age in parallel with the first laying age. The effects of light stimulation age on egg yield and hatching egg yield were found significant.

Egg yield

Egg weight

Hatching egg yield

In NLS treatment all pure-lines, 5 more eggs were produced in egg yield and hatching egg yield. However, differences in egg yield and weight in pure-lines were found significant. The study results showed that the egg production can be increased by first light stimulation at the 20 weeks of age, provided that at least $2 \mathrm{~kg}$ live weight is achieved in broiler pure-lines.

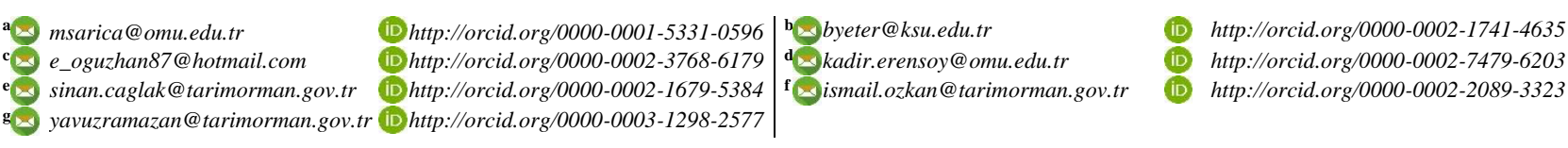

(c) (1) ) T) This work is licensed under Creative Commons Attribution 4.0 International License

\section{Introduction}

Parental materials used in broiler production are distributed to the production areas with the effective organization of a few breeding companies in today. Breeding companies apply intensive selection at the level of pure-lines and ensure the production of grandparents, parents and hybrids with the contribution of heterotic effects arising from crossings in later stages. All the desired production traits in broiler chicken production are achieved by selection at the level of pure-lines. In accordance with these demands, some changes are made in the traits of the grandparents with the selection applied on pure-lines in 24 years (Arthur and Albers, 2003).

While the highest live weight is aimed in the broiler breeding, it is aimed to have sufficient reproductive efficiency. The negative correlation of these two traits is the biggest challenge in broiler breeding. For this purpose, in the breeding companies, sire lines where growth traits (fast growth, feed efficiency, etc.) are concentrated and the dam lines where reproductive traits (egg yield, fertility, hatching traits, etc.) are concentrated have been developed. It is also possible to develop pure-lines in terms of sex determination (feathering rate), meat quality, breast meat ratio and composition of meat in broiler pure-lines. The fact that they are homozygous to a significant level with effective selection for certain traits requires the production practices to be more sensitive. Difficulties in obtaining offspring for reproduction traits can be observed, especially in line production, depending on the degree of homozygosity (Decuypere et al., 2003; Remignon and Le Bihan-Duval, 2003). 
Especially during the rearing period, live weight is controlled with restricted lighting and feeding programs for optimization of reproduction in the broiler pure-lines and parents (Anonymous, 2019 a, b; Ferreira et al., 2019). Flock uniformity, first laying age and reaching the hatching egg weight in a short time are closely related to practices during the growing period (Mitrovic et al., 2010; Willems et al., 2013; Gous and Danisman, 2016). It is important for broiler parents to be close to their adult weight in order for their reaction to light stimulation to occur. This period can occur between 18-22 weeks of age in broiler parents. Therefore, it is stated that the first light stimulation in commercial applications can be initiated between 120-160 days of age (Robinson et al., 1996; Leeson and Summers, 2000; Ferreira et al., 2019). Light stimulation age varies globally and this can affect the production performance of broiler breeders. On the other hand, genetically heavy lines reach sexual maturity later ages (Leeson and Summers, 2000). In some regions, breeders are stimulated at the 21 weeks of age, while in other regions the minimum hatching egg weight (50-52 $\mathrm{g}$ ) is taken into account and stimulation is performed at the 23 weeks of age (Joseph et al., 2002). There are also studies indicating that light stimulation age does not affect total egg production (Renema et al., 2001; Joseph et al., 2002). Light stimulation at earlier age causes small egg production, as well as egg weight differences in the laying period of parent, grand-parent and pure-line flocks (Yuan et al., 1994; Robinson et al., 1996; Gous and Cherry, 2004; Stacey et al., 2004; Lewis and Gous, 2006; Anonymous, 2019a ).

In this study, the effects of light stimulation at normal (154 d: 22 wks) and early (140 d: 20 wks) age on some physiological and reproductive traits in 4 dam and 2 sire lines were carried out during the laying period.

\section{Material and Methods}

This study was carried out with the dam pure-lines named A1, A2, A3, A4 and the sire pure-lines named B1 and B2, whose breeding studies were carried out in "Eskişehir Geçit Kuşağı Agricultural Research Institute". In order to produce enough chicks for light stimulation treatments, two hatches were made at 14 days intervals. During the rearing period, the same conditions were provided in terms of selection practices, feeding, live weight controls, lighting, heating, health protection and environment in chicks.

The chicks were reared in 4-tier cage system with 10 chicks in each cage (length: $123 \mathrm{~cm}$, depth: $67 \mathrm{~cm}$ and height: $40 \mathrm{~cm}$ ) until 10 weeks of age. Chicks that were individually selected according to live weight and feed conversion ratio at the first 10 weeks of age and were placed individually in 3-tier cages with 60x62x44 cm sizes from 11 to 15 weeks of age.

At the 15 weeks of age, selection was made according to breast width and body weight, and the selected chicks were placed in littered-floor with wire-surrounded family pens in $2 \times 2.5 \mathrm{~m}$ sizes in the laying house. 10 birds were placed in each family pens $\left(2\right.$ hens $\left./ \mathrm{m}^{2}\right)$. Rearing, growing and egg laying houses are closed and environmentally controlled houses and have heating, ventilation, lighting and cooling systems. Optimum conditions were provided during the rearing and laying period of pure lines.
Chicks were kept at the same lighting duration and intensity until they were 20 weeks of age. In the laying house, light stimulation was applied to the first hatched hens at the 154 days of age (NLS: Normal), to the second hatched hens at the of 140 days of age (ELS: Early) for 2 hours (12 hours daily lighting). At 25 weeks of age for NLS hens and at 23 weeks of age for ELS hens, 15 hours lighting was applied and this time was kept constant throughout the laying period (Table 1). Light intensity measured with MS 6610, V\&A model luxmeter at feeder level.

Nutrient compositions of feeds used in different periods of the study are given in Table 2. Ad-libitum feeding was provided during the first two weeks of age, and in the following weeks, restricted feeding was performed according to weekly body weight controls in chicks. The amount of feed for the next week was determined according to the body weight controls performed every week. Chickens were fed with grill-type feeders in family pens during the laying period, and $15 \mathrm{~cm}$ feeder length was provided per hen. Roosters are prevented from eating the hens feed with $44 \mathrm{~mm}$ wide grill wires. For the roosters, tube feeders were used, which are placed at a height that hens cannot reach. Feed consumption was calculated at family level and given as daily. Water was provided free and 3 nipple drinkers were used in each family pen. Health protection measures were taken into account and vaccinations used for broiler parents were carried out in accordance with the schedule. No disease occurred during the rearing and laying period.

In the rearing period, live weight and feed consumption were determined. During the laying period, first laying age, $50 \%$ yield age and live weights at different ages were determined. Egg yield and hatching egg yields were determined as number, egg weights were determined every week at the same day until the end of the 43 weeks of age. The data obtained were evaluated with two-factor analysis of variance according to light stimulation and pure-lines. Analyses were made with SPSS statistical package program. Duncan multiple comparison test was used to compare the averages of the traits considered between pure-lines.

\section{Results and Discussion}

\section{Live weight}

Live weights of the NLS and ELS hens did not differ at 20 weeks of age. Due to the different levels of selection made to the lines, it is natural that the live weights before laying are similar in same line. During the rearing period (up to 20 weeks of age), daily feed intake was $47.0 \mathrm{~g}$ (total $6.58 \mathrm{~kg}$ for 20 weeks) and $47.3 \mathrm{~g}$ (total $6.62 \mathrm{~kg}$ for 20 weeks) per hen in NLS and ELS groups, respectively. The daily feed intake was $46.9 \mathrm{~g}$ (total $6.57 \mathrm{~kg}$ for 20 weeks) in the NLS group and $47.2 \mathrm{~g}$ (6.61 kg for 20 weeks) in the ELS group in the dam lines, respectively (A1, A2, A3 and $\mathrm{A} 4)$. In the B1 and B2 sire lines, the daily feed intake was

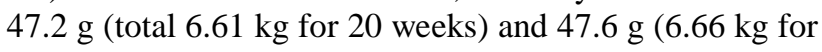
20 weeks), respectively. It is recommended to reach at least $2 \mathrm{~kg}$ live weight for the first light stimulation in broiler parents (Robinson et al., 1998; Gous and Cherry, 2004; Anonymous, 2019a,b). In broiler parents, the 20-22 weeks of age is generally considered appropriate for the first light stimulation and it is aimed to start laying at the 24 weeks 
of age. On the other hand, due to the short egg production period of the parents (40 weeks), early light stimulation that will enable laying to be initiated at 21 weeks of age is emphasized (Yuan et al., 1994; Leeson and Summers, 2000). Feed intake and live weight values increased with first light stimulation in NLS and ELS groups. Live weights were over $2.5 \mathrm{~kg}(2555.20 \mathrm{~g}$ in NLS and 2588.97 $\mathrm{g}$ in ELS hens) at 24 weeks of age and it was determined over $4 \mathrm{~kg}$ (4079.08 $\mathrm{g}$ in NLS and $4123.57 \mathrm{~g}$ in ELS hens) at the 43 weeks of age and the differences between the NLS and ELS hens were not significant. While feeding and other applications are carried out during the rearing period according to the target live weight for the parents used in commercial production. It is natural that there are some differences in pure lines where breeding practices are performed compared to parents (Leeson and Summers, 2000; Mitrovic et al., 2010).

Although there were similarities between the live weights of NLS and ELS groups at different ages, the differences between the pure lines were significant at 20 , 24 and 43 weeks of age $(\mathrm{P}<0.05)$. With the effect of more efficient selection for live weight in sire lines, higher body weights were determined in these groups at all ages. On the other hand, although the differences in live weights were not significant at 20 and 24 weeks of age in the dam lines, it was observed that the A2 line was heavier in all ages (Table 3). This situation fits a line structuring suitable for the hybrid production program with crossing in the sire and dam lines (Leeson and Summers, 2000). In the rearing period, in Ross308 parents, 8-9 h lighting is applied up to 10 weeks of age. In a study, a group of $11 \mathrm{~h}$ at 20 weeks of age and $15 \mathrm{~h}$ light at 27 weeks of age were compared with parents that received $11 \mathrm{~h}$ at 20 weeks of age and $16 \mathrm{~h}$ light at 28 weeks of age. However, it was stated that there was no difference between these lighting treatments in terms of live weights at the 20, 24 and 42 weeks of age (Usturoi et al., 2009). Light stimulation has a significant effect on body weight and egg production traits after 20 weeks of age, depending on live weight in the growth period (Lewis and Gous, 2006), this situation is partially compatible with our results.

\section{Egg Production Traits}

The effects of NLS and ELS on first laying age and $\% 50$ yield age were found significant in broiler pure lines $(\mathrm{P}<0.05)$. Whereas NLS hens reached to the first laying age at 172 days, in ELS hens the first egg was seen at the 165 days of age. The $\% 50$ yield ages were realized at 184 and 176 days of age in parallel with these values in NLS and ELS hens, respectively $(\mathrm{P}<0.05)$. While $\mathrm{A} 1, \mathrm{~A} 3$ and $\mathrm{A} 4$ lines reached to first laying age and $50 \%$ production earlier than A2, B1 and B2 lines ( $\mathrm{P}<0.05$; Table 3 ). The $50 \%$ yield age is the most important indicator of sexual maturity age in hens and is one of the most considered traits in commercial production (Leeson and Summers, 2000; Türkoğlu and Sarıca, 2018).

The effects of light stimulation age on egg yield and hatching egg yield were found significant $(\mathrm{P}<0.05)$, and ELS hens produced 5 more eggs in both yield traits. On the other hand, light stimulation was not affected to egg weight. Differences between pure lines in terms of egg yield, hatching egg yield and egg weight were found significant $(\mathrm{P}<0.05)$. Egg yields were found higher in $\mathrm{A} 1$, A2, A3 and A4 dam lines (between 85.4 and 99.9 eggs), thus hatching egg yields were higher in these lines (between 83.5 and 95.3 eggs) compared to sire lines. In addition, 75.9 and 81.07 eggs and 73.5 and 78.8 hatching eggs were obtained in the B1 and B2 sire lines, respectively.

100

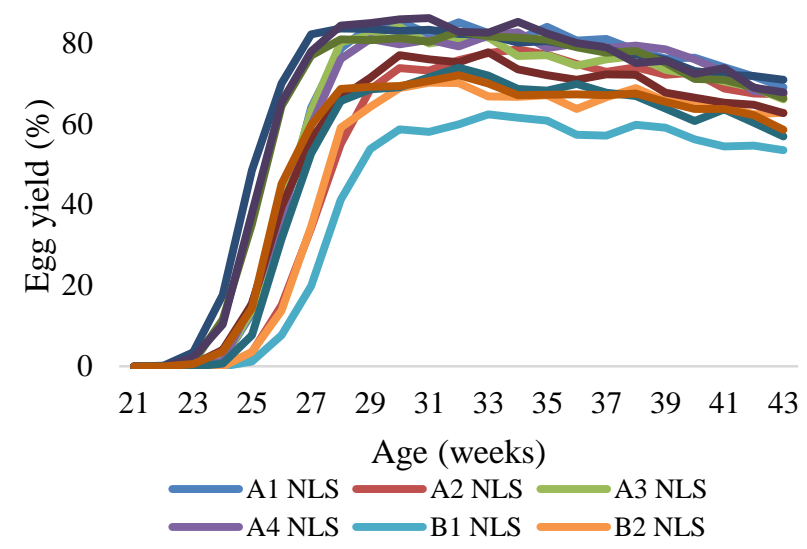

Figure 1. Weekly egg yield changes in NLS and ELS broiler pure-lines $(\%)$

70

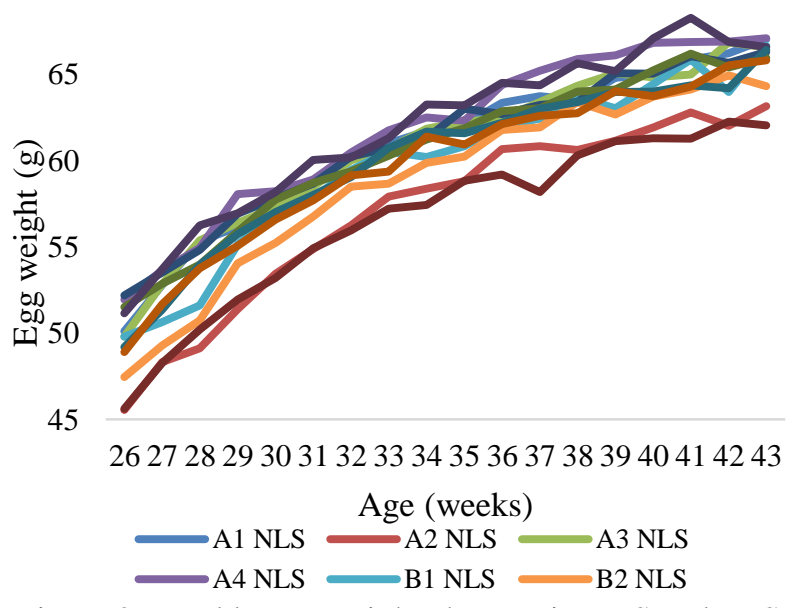

Figure 2. Weekly egg weight changes in NLS and ELS broiler pure-lines $(\mathrm{g})$

Table 1. Lighting program, light stimulation and intensity during the study

\begin{tabular}{l|ccc}
\hline \multicolumn{1}{c|}{ NLS } & ELS & $\begin{array}{c}\text { Lighting duration Light intensity } \\
(\mathrm{h})\end{array}$ & $($ lux $)$ \\
\hline 1 & 1 & 23 & \\
2 & 2 & 22 & $80-100$ \\
3 & 3 & 18 & \\
4 & 4 & 16 & \\
5 & 5 & 16 & $30-40$ \\
6 & 6 & 14 & \\
7 & 7 & 14 & $5-10$ \\
8 & 8 & 12 & $40-50$ \\
9 & 9 & 12 & $80-90$ \\
$10-153$ & $10-139$ & 10 & 12 \\
$154-174$ & $140-160$ & 15 & \\
$175-301$ & $161-301$ & 15 &
\end{tabular}


Table 2. Nutrient composition of feeds used in different periods of the study

\begin{tabular}{|c|c|c|c|c|c|c|c|c|c|c|}
\hline \multicolumn{11}{|l|}{ Nutrient compositions } \\
\hline Crude protein $\%$ & \multicolumn{2}{|c|}{20.0} & \multicolumn{2}{|c|}{18.0} & \multicolumn{2}{|c|}{$14.0-15.0$} & \multicolumn{2}{|c|}{$14.5-15.5$} & \multicolumn{2}{|c|}{$16.0-17.0$} \\
\hline Energy kCal & \multicolumn{2}{|c|}{2750} & \multicolumn{2}{|c|}{2750} & \multicolumn{2}{|c|}{2630} & \multicolumn{2}{|c|}{2750} & \multicolumn{2}{|c|}{2750} \\
\hline Energy MJ & \multicolumn{2}{|c|}{11.5} & \multicolumn{2}{|c|}{11.5} & \multicolumn{2}{|c|}{11.0} & \multicolumn{2}{|c|}{11.5} & \multicolumn{2}{|c|}{11.5} \\
\hline Crude fiber Max, $\%$ & \multicolumn{2}{|c|}{7} & \multicolumn{2}{|c|}{7} & \multicolumn{2}{|c|}{7} & \multicolumn{2}{|c|}{7} & \multicolumn{2}{|c|}{7} \\
\hline Amino acids $\%$ & $\mathrm{~T}$ & A & $\mathrm{T}$ & A & $\mathrm{T}$ & A & $\mathrm{T}$ & A & $\mathrm{T}$ & A \\
\hline Arginine $\%$ & 1.17 & 1.03 & 0.95 & 0.83 & 0.67 & 0.59 & 0.64 & 0.57 & 0.73 & 0.63 \\
\hline Iso-leucine $\%$ & 0.79 & 0.67 & 0.65 & 9.55 & 0.46 & 0.39 & 0.51 & 0.43 & 0.55 & 0.47 \\
\hline Lysine \% & 1.12 & 0.96 & 0.91 & 0.78 & 0.64 & 0.55 & 0.64 & 0.55 & 0.71 & 0.61 \\
\hline Methionine \% & 0.46 & 0.42 & 0.38 & 0.34 & 0.27 & 0.24 & 0.30 & 0.27 & 0.32 & 0.29 \\
\hline Met. + Cystine \% & 0.87 & 0.74 & 0.73 & 0.62 & 0.52 & 0.44 & 0.53 & 0.46 & 0.58 & 0.50 \\
\hline Thyrionine \% & 0.73 & 0.60 & 0.61 & 0.51 & 0.43 & 0.36 & 0.47 & 0.39 & 0.51 & 0.43 \\
\hline Tryptophan \% & 0.19 & 0.16 & 0.15 & 0.13 & 0.11 & 0.09 & 0.15 & 0.13 & 0.17 & 0.14 \\
\hline \multicolumn{11}{|l|}{ Minerals } \\
\hline Calcium \% & \multicolumn{2}{|c|}{1.00} & \multicolumn{2}{|c|}{1.00} & \multicolumn{2}{|c|}{1.00} & \multicolumn{2}{|c|}{1.50} & \multicolumn{2}{|c|}{2.80} \\
\hline A.phosphorus $\%$ & \multicolumn{2}{|c|}{0.45} & \multicolumn{2}{|c|}{0.45} & \multicolumn{2}{|c|}{0.35} & \multicolumn{2}{|c|}{0.40} & \multicolumn{2}{|c|}{0.35} \\
\hline Magnesium \% & \multicolumn{2}{|c|}{$0.05-0.10$} & 0.0 & .10 & & & & & 0.0 & 10 \\
\hline Sodium \% & & & & & & & & & & \\
\hline Chlorine \% & 0.16 & 0.22 & 0.16 & .22 & & & & & 0.1 & 22 \\
\hline Potassium \% & 0.40 & 0.90 & 0.40 & .90 & & & & & 0.6 & 90 \\
\hline Colin/kg mg/kg & & & & & & & & & & \\
\hline Linoleic acid \% & & & & & & & & & & \\
\hline
\end{tabular}

T: Total; A: Available; *Trace minerals and vitamins are added as a premix.

Table 3. Effects of light stimulation age on live weight and egg production traits

\begin{tabular}{|c|c|c|c|c|c|c|c|c|c|}
\hline \multirow{2}{*}{$\mathrm{LS}$} & \multirow{2}{*}{ PL } & \multicolumn{2}{|c|}{ Yield age $(\mathrm{d})$} & \multicolumn{2}{|c|}{ Egg yield (n) } & \multirow{2}{*}{ EW (g) } & \multicolumn{3}{|c|}{ LW (g) } \\
\hline & & First egg & $\% 50$ & Total & Hatching & & W 20 & W 24 & W 43 \\
\hline \multirow{6}{*}{ NLS } & $\mathrm{A} 1(28)^{1}$ & 169.14 & 180.07 & 96.84 & 92.11 & 60.85 & 2074.00 & 2468.50 & 3968.80 \\
\hline & A2 (19) & 174.37 & 187.68 & 84.08 & 82.07 & 57.15 & 2120.00 & 2511.03 & 4090.00 \\
\hline & A3 (14) & 168.64 & 178.00 & 93.60 & 88.69 & 60.76 & 2099.64 & 2502.14 & 4002.33 \\
\hline & A4 (7) & 168.14 & 179.86 & 94.69 & 90.67 & 61.79 & 2088.00 & 2495.50 & 4078.00 \\
\hline & B1 (11) & 177.00 & 190.09 & 65.53 & 63.05 & 60.11 & 2241.25 & 2716.00 & 4238.67 \\
\hline & B2 (14) & 174.43 & 188.07 & 77.22 & 74.97 & 58.91 & 2219.20 & 2638.00 & 4096.67 \\
\hline \multirow{6}{*}{ ELS } & A1 (25) & 159.68 & 170.56 & 103.41 & 98.85 & 60.93 & 2091.17 & 2510.00 & 3930.25 \\
\hline & A2 (15) & 166.53 & 179.47 & 87.16 & 85.19 & 56.64 & 2124.67 & 2556.67 & 4226.00 \\
\hline & A3 (20) & 162.50 & 173.70 & 99.70 & 95.44 & 60.56 & 2110.75 & 2548.50 & 4029.00 \\
\hline & A4 (6) & 163.50 & 172.67 & 102.13 & 98.27 & 61.82 & 2070.25 & 2494.00 & 4036.67 \\
\hline & B1 (22) & 170.86 & 180.77 & 81.10 & 78.74 & 60.07 & 2330.26 & 2746.67 & 4327.50 \\
\hline & B2 (23) & 166.04 & 178.13 & 83.42 & 81.20 & 59.77 & 2241.00 & 2678.00 & 4192.00 \\
\hline SEM & & 0.340 & 0.251 & 0.478 & 0.489 & 0.093 & 6.986 & 9.797 & 13.055 \\
\hline \multicolumn{10}{|c|}{ Effects } \\
\hline \multirow{3}{*}{ LS } & & $0.000 * *$ & $0.000 * *$ & $0.000 * *$ & $0.000^{* *}$ & $0.839 \mathrm{NS}$ & $0.134 \mathrm{NS}$ & $0.086 \mathrm{NS}$ & $0.099 \mathrm{NS}$ \\
\hline & NLS (93) & 171.95 & 183.69 & 86.92 & 83.42 & 59.77 & 2140.35 & 2555.20 & 4079.08 \\
\hline & ELS(111) & 164.85 & 176.04 & 91.91 & 88.71 & 59.92 & 2161.35 & 2588.97 & 4123.57 \\
\hline \multirow{7}{*}{ PL } & & $0.000^{* *}$ & $0.000 * *$ & $0.000 * *$ & $0.000^{* *}$ & $0.000^{* *}$ & $0.000 * *$ & $0.000 * *$ & $0.000 * *$ \\
\hline & A1 (53) & $164.68^{c}$ & $175.58^{\mathrm{c}}$ & $99.94^{\mathrm{a}}$ & $95.29^{a}$ & $60.89^{b}$ & $2080.44^{c}$ & $2486.94^{c}$ & $3951.67^{d}$ \\
\hline & A2 (34) & $170.91^{\mathrm{ab}}$ & $184.06^{\mathrm{a}}$ & $85.44^{\mathrm{b}}$ & $83.45^{\mathrm{b}}$ & $56.92^{\mathrm{e}}$ & $2122.33^{c}$ & $2534.24^{\mathrm{c}}$ & $4158.00^{b}$ \\
\hline & A3 (34) & $165.03^{c}$ & $175.47^{\mathrm{c}}$ & $97.19^{\mathrm{a}}$ & $92.66^{\mathrm{a}}$ & $60.65^{b c}$ & $2106.18^{c}$ & $2529.41^{\mathrm{c}}$ & $4017.57^{\mathrm{cd}}$ \\
\hline & A4 (13) & $166.00^{c}$ & $176.54^{\mathrm{c}}$ & $98.12^{\mathrm{a}}$ & $94.18^{\mathrm{a}}$ & $61.80^{\mathrm{a}}$ & $2079.13^{c}$ & $2494.75^{\mathrm{c}}$ & $4057.33^{c}$ \\
\hline & B1 (33) & $172.91^{\mathrm{a}}$ & $183.88^{\mathrm{a}}$ & $75.91^{\mathrm{d}}$ & $73.51^{\mathrm{d}}$ & $60.08^{c}$ & $2300.08^{a}$ & $2736.27^{\mathrm{a}}$ & $4289.43^{\mathrm{a}}$ \\
\hline & B2 (37) & $169.22^{b}$ & $181.89^{b}$ & $81.07^{c}$ & $78.84^{\mathrm{c}}$ & $59.45^{\mathrm{d}}$ & $2233.73^{\mathrm{b}}$ & $2664.67^{\mathrm{b}}$ & $4151.14^{b}$ \\
\hline $\mathrm{LS} \times \mathrm{PL}$ & & $0.314 \mathrm{NS}$ & $0.004 * *$ & $0.004 * *$ & $0.005 * *$ & $0.282 \mathrm{NS}$ & $0.413 \mathrm{NS}$ & $0.989 \mathrm{NS}$ & $0.269 \mathrm{NS}$ \\
\hline
\end{tabular}

LS: Light stimulation; PL: Pure lines; NLS: Light stimulation at normal age; ELS: Light stimulation at early age; ${ }^{1}$ : Number of families (10 hens in each family); EW: Egg weight; LW: Live weight; **: P<0.01; NS: No significance; a,b,c,d: According to Duncan test results, differences between pure line mean values indicated with different letters are significant $(\mathrm{P}<0.05)$.

Light stimulation $\mathrm{x}$ pure line interactions were found significant in egg yield and hatching egg yield. Dam and sire lines had similar egg weights. The change in egg yield and egg weight according to light stimulation ages in pure lines is given in Figure 1 and Figure 2. Some differences were found in egg yield values between lines depending on peak yield and the hatching egg weight and fluctuations in the laying period.

In the feeding program of pure lines, body weight, egg yield and egg weight were taken into consideration after the light stimulation. Average daily feed intake of NLS hens was $150 \mathrm{~g}$ (between 120-170 g) during the laying 
period, while it was $154 \mathrm{~g}$ (between $120-170 \mathrm{~g}$ ) in ELS hens. There was no difference between NLS and ELS groups during the laying period in terms of liveability $(97.4$ to $99 \%)$, double egg $(0.6$ to $1.1 \%)$ and prolapsus $(0.0$ to $0.5 \%$ ) in the lines.

Since the most important factor at the first light stimulation age is the live weight of hens, early light stimulation decreases the egg yield and weight in the laying period in hens with lower live weight (Robinson and Robinson, 1991; Melnychuk et al., 2004). Therefore, light stimulation is delayed until the 22-23 weeks of age to reach the appropriate live weight (Robinson et al., 1996; Sun and Coon, 2005; Renema et al., 2007). However, delaying light stimulation to 23 weeks of age in flocks where there is little variation in live weight is not effective neither in the sexual maturity age nor in increasing egg production (Lewis and Gous, 2006; Romero et al., 2009; van der Klein et al., 2018). In our study, live weight uniformity was achieved at a very good level (coefficient of variation in the dam lines of 3.2 to $4.8 \%$; in sire lines 3.4 to $3.9 \%$ ). In addition, the target of $2 \mathrm{~kg}$ live weight at 20 weeks of age has been achieved in all lines. Therefore, it has been determined that ELS treatment has advantages compared to NLS. In order to ensure a good uniformity in commercial production, live weight controlled feeding program and light stimulation at the appropriate age are considered as basic rules for high reproduction efficiency (Gous and Cherry, 2004; Anonymous, 2019a,b). By fulfilling these conditions, an improvement in egg production can be achieved by light stimulation at the 20 weeks of age in pure broiler pure lines or great-grand parents. Additional studies are needed to determine the effect of light stimulation at earlier ages. However, it can be considered to increase egg production without adversely affecting the biological and physiological status of broiler pure lines.

\section{Acknowledgements}

The authors thank the responsible and technical staff in "Eskişehir Geçit Kuşağı Agricultural Research Institute" for their great efforts in the improvement and selection studies of the pure line materials in the study, and "TAGEM" institution for financial support for the project.

\section{References}

Anonymous. 2019a. Aviagen Manual, Pocket Guide Production 20 weeks to depletion, Ross an Aviagen Brand.

Anonymous. 2019b. Cobb Manual, Cobb-500 and Cobb-700 Breeder Management Guide.

Arthur, JA, Albers GAA. 2003. International perspective on problems and issues associated with poultry breeding. Poultry Genetics, Breeding and Biotechnology (Edited by W.M. Muir and S.E. Aggrey), 1-12, Cabi Publishing UK. doi: 10.1079/9780851996608.0000.

Decuypere E, Bruggeman V, Barbato GF, Buyse J. 2003. Growth and reproduction problems associated with selection for increased broiler meat production. Poultry Genetics, Breeding and Biotechnology (Edited by W.M. Muir and S.E. Aggrey), 13-28, Cabi Publishing UK. doi: 10.1079/9780851996608.0000.

Ferreira NT, Sakomura NK, Gous RM. 2019. Consequences of lighting program in rearing phase and its effects of amino acid requirements in broiler breeder flock in egg production. Animal Feed Science and Technology, 253: 153-165. doi: 10.1016/j.anifeedsci.2019.05.019.
Gous RM, Cherry P. 2004. Effects of body weight at, and lighting regimen and growth curve to, 20 weeks on laying performance in broiler breeders. British Poultry Science, 45(4): 445-452. doi: 10.1080/00071660400001256.

Gous RM, Danisman R. 2016. Age, lighting treatment, feed allocation and feed form influence broiler breeder feeding time. South African Journal of Animal Science, 46(1): 29-34. doi: 10.4314/sajas.v46i1.4.

Joseph NS, Dulaney AA, Robinson FE, Renema RA, Zuidhof MJ. 2002. The effects of age at photo stimulation and dietary protein intake on reproductive efficiency in three strains of broiler breeders varying in breast yield. Poultry Science, 81(5): 597-607. doi: 10.1093/ps/81.5.597.

Leeson S, Summers JD. 2000. Broiler Breeder Production. Context Products Ltd, LE65 1WN, England. ISBN 978-1904761-79-2.

Lewis PD, Gous RM. 2006. Effect of final photoperiod and twenty-week body weight on sexual maturity and early production in broiler breeders. Poultry Science, 85: 377-383. doi: 10.1093/ps/85.3.377.

Melnychuk VL, Kirby JD, Kirby YK, Emmerson DA, Antony NB. 2004. Effect of strain, feed allocation program, and age at photo stimulation on reproductive development and carcass characteristics of broiler breeder hens. Poultry Science, 83: 1861-1867. doi: 10.1093/ps/83.11.1861.

Mitrovic S, Dermanovic V, Radivojevic M, Ralevic N, Ostojic D. 2010. Possibilities of more efficient usage of genetic potential of broilers breeders. African Journal of Biotechnology, 9(18): 2584-2594. ISSN 1684-5315.

Remignon H, Le Bihan-Duval E. 2003. Meat quality problems associated with increased production. Poultry Genetics, Breeding and Biotechnology (Edited by W.M. Muir and S.E. Aggrey), 53-66, Cabi Publishing UK. doi: 10.1079/ 9780851996608.0000.

Renema RA, Robinson FE, Goerzen PR, Zuidhof MJ. 2001. Effects of altering growth curve and age at photostimulation in female broiler breeders. 2. Egg production parameters. Canadian Journal of Animal Science, 81(4): 477-486. doi: 10.4141/A00-109.

Renema RA, Robinson FE, Zuidhof MJ. 2007. Reproductive efficiency and metabolism of female broiler breeders as affected by genotype, feed allocation, and age at photo stimulation. 2. Sexual maturation. Poultry Science, 86(10): 2267-2277. doi: 10.1093/ps/86.10.2267.

Robinson FE, Renema RA, Bouvier L, Feddes JJR, Wilson JL, Newcombe M, McKay RI. 1998. Effects of photo stimulatory lighting and feed allocation in female broiler breeders 1 . Reproductive development. Canadian Journal of Animal Science, 78(4): 603-613. doi: 10.4141/A98-017.

Robinson FE, Robinson NA. 1991. Reproductive performance, growth rate and body composition of broiler breeder hens differing in body weight at 21 weeks of age. Canadian Journal of Animal Science, 71: 1223-1231. doi: 10.4141/cjas91-145.

Robinson FE, Wauter T, Hardin RT. 1996. Effects of age at photo stimulation on reproductive efficiency and carcass characteristics. Canadian Journal of Animal Science, 76: 275282. doi: 10.4141/cjas96-042.

Romero LF, Renema RA, Naeima A, Zuidhof MJ, Robinson F. 2009. Effect of reducing body weight variability on the sexual maturation and reproductive performance of broiler breeder females. Poultry Science, 88: 445-452. doi: 10.3382/ps.200800165 .

Stacey KF, Parsons DJ, Frost AR, Fisher C, Filmer D, Fothergill A. 2004. An automatic growth and nutrition control system for broiler production. Biosystems Engineering, 89(3): 363371. doi: 10.1016/j.biosystemseng.2004.07.006.

Sun J, Coon CN. 2005. The effects of body weight, dietary fat, and feed withdrawal rate on the performance of broiler breeders. Journal of Applied Poultry Research, 14(4): 728739. doi: $10.1093 / \mathrm{japr} / 14.4 .728$. 
Türkoğlu M, Sarıca M. 2018. Tavuk genetiği ve 1slahı. Tavukçuluk Bilimi, Yetiştirme Besleme, Hastalıklar. (Editörler M.Türkoğlu ve M.Sarıca), 324-370.

Usturoi MG, Vacaru-Opriş I, Ciocan I, Radu-Rusu RM, Usturoi A. 2009. Improvement of the morpho-productive indexes at the Ross-308 broiler breeders, through increased photo stimulation. Universitatea de Ştiinţe Agricole şi Medicine Veterinary Iasi, 52: 260-265.
Van der Klein SAS, Bedecarrats GY, Robinson FE, Zuidhof MJ. 2018. Early photo stimulation at the recommended body weight reduced broiler breeder performance. Poultry Science, 97: 3736-3745. doi: 10.3382/ps/pey215.

Willems OW, Miller SP, Wood BJ. 2013. Aspects of selection for feed efficiency in meat producing poultry. World's Poultry Science Journal, 69: 77-87. doi: 10.1017/S00439339 $1300007 X$.

Yuan T, Lien RJ, McDaniel GR. 1994. Effects of increased rearing period body weights and early photo stimulation on broiler breeder egg production. Poultry Science, 73: 792-800. doi: 10.3382/ps.0730792. 